\title{
Plant Regeneration via Somatic Embryogenesis in Larix principis-rupprechtii Mayr
}

\author{
Shuaifei Jiang ${ }^{1,+}$, Xiaoyi Chen ${ }^{1,+}$, Ying Gao ${ }^{2}$, Ying Cui ${ }^{2}$, Lisheng Kong ${ }^{2,3}$, Jian Zhao ${ }^{1,2, *}$ and Jinfeng Zhang ${ }^{1,2, *}$ \\ 1 College of Biological Sciences and Biotechnology, Beijing Forestry University, National Engineering \\ Laboratory for Tree Breeding, Beijing 100083, China; jiangfei435414605@126.com (S.J.); \\ cxy919@bjfu.edu.cn (X.C.) \\ 2 Beijing Advanced Innovation Center for Tree Breeding by Molecular Design, Beijing 100083, China; \\ gying@zju.edu.cn (Y.G.); cwfpyl@126.com (Y.C.); lkong@uvic.ca (L.K.) \\ 3 Centre for Forest Biology, Department of Biology, University of Victoria, 3800 Finnerty Rd, \\ Victoria, BC V8W 3N5, Canada \\ * Correspondence: zhaojian0703@bjfu.edu.cn (J.Z.); zjf@bjfu.edu.cn (J.Z.) \\ + Shuaifei Jiang and Xiaoyi Chen contributed equally to this work.
}

check for

updates

Citation: Jiang, S.; Chen, X.; Gao, Y.; Cui, Y.; Kong, L.; Zhao, J.; Zhang, J. Plant Regeneration via Somatic Embryogenesis in Larix principis-rupprechtii Mayr. Forests 2021, 12, 1335. https://doi.org/10.3390/ f12101335

Received: 18 August 2021

Accepted: 27 September 2021

Published: 29 September 2021

Publisher's Note: MDPI stays neutral with regard to jurisdictional claims in published maps and institutional affiliations.

Copyright: (c) 2021 by the authors. Licensee MDPI, Basel, Switzerland. This article is an open access article distributed under the terms and conditions of the Creative Commons Attribution (CC BY) license (https:/ / creativecommons.org/licenses/by/ $4.0 /)$.
Abstract: Prince Rupprecht's larch (Larix principis-rupprechtii Mayr) is a native conifer in North China with great economic and ecological values. Somatic embryogenesis (SE) is a powerful tool for the mass clonal propagation in plants. In this study, we described a high-efficiency SE system via indirect pathways and investigated the effect of genotype, culture conditions and phytohormones on SE. Immature zygotic embryos (IZEs) of L. principis-rupprechtii Mayr were used as explant materials. In the induction stage, embryogenic tissues (ETs) were induced on mLV medium supplemented with $2.0 \mathrm{mg} \mathrm{L}^{-1}$ 2,4-dichlorophenoxyacetic acid (2,4-D) and $1.0 \mathrm{mg} \mathrm{L}^{-1}$ 6-benzylaminopurine (6-BA). The initiation frequencies showed significant differences $(p<0.05)$ among 20 genotypes of open-pollinated mother trees with the highest induction frequency reaching 30\%. For tissue proliferation, proliferation in liquid medium was more efficient compared with proliferation in semi-solid medium, providing a multiplication rate of 3.12 in an 8-day subculture period. As a necessary exogenous plant growth regulator (PGR) for somatic embryo maturation in conifers, abscisic acid (ABA) was optimized at $16 \mathrm{mg} \mathrm{L}^{-1}$ in this system. Next, an orthogonal test on osmotic pressure factors showed $50 \mathrm{~g} \mathrm{~L}^{-1}$ sucrose, $7 \mathrm{~g} \mathrm{~L}^{-1}$ phytagel and $75 \mathrm{~g} \mathrm{~L}^{-1}$ polyethylene glycol (PEG) was the optimal combination for somatic embryo maturation in L. principis-rupprechtii Mayr. Moreover, the dispersion culture method provided a more efficient somatic embryo maturation, up to 545 per gram of fresh weight (FW). Finally, $2 \mathrm{~g} \mathrm{~L}^{-1}$ of active charcoal (AC) was found to increase the somatic embryo germination rate to $63.46 \%$. The improved protocol of SE will serve as a foundation for establishing mass propagation and genetic transformation of L. principis-rupprechtii Mayr.

Keywords: conifer; larch; somatic embryos; genotype; culture methods; phytohormones

\section{Introduction}

Prince Rupprecht's larch (Larix principis-rupprechtii Mayr.), a deciduous conifer, widely grows in middle and high elevations of Northern China. Its natural populations are mainly distributed at middle and high elevations (1400-2800 m) in Shanxi and Hebei Provinces [1]. Due to its wide ecological plasticity, rapid growth, and desirable wood product, it has become one of the major tree species for timber and afforestation and plays a critical role in reforestation programs and commercially.

In vitro propagation technologies offer opportunities to expedite mass clonal propagation of elite trees, including those of rare or threatened species [2]. The conventional propagation method of Prince Rupprecht's larch is seed propagation or vegetative propagation. However, due to the long seed propagation cycle, low germination rate, low vegetative cutting propagation coefficient, age effect, position effect, and difficulty in obtaining materials, it is difficult to meet the requirements of large-scale planting. Somatic 
embryogenesis (SE) is a more effective and genetically stable method for rapid propagation of plants than other vegetative propagation [3], and it also has been the most important development for plant tissue culture, which involves the in vitro production of plants or embryos from single haploid or diploid somatic cells without cell fusion [4]. It is much like its zygotic counterparts, with obvious bipolar structures [5]. Therefore, SE is a replay of zygotic embryogenesis, which provides a desirable model for studying the development of embryos. It is not only for mass propagation but also for enabling the implementation of biotechnological tools that can be used to increase the productivity and wood quality of plantation forestry [6].

Research on SE of conifers started in the 1980s, Hakman obtained regenerated plants from immature zygotic embryos (IZEs) of Norway spruce [7]. To date, at least 50 coniferous species are reported to go through SE [8], and it has been become an important technique for mass propagation of multiple coniferous species, such as Loblolly pine (Pinus taeda L.), one of the most important commercial trees in the United States, its SE technology has been continuously optimized and successfully used for commercial purposes [9]. At Weyerhaeuser Company, Douglas-fir somatic embryo production in liquid medium and manufactured seed delivery has been developed to reduce labor costs and increase efficiency of mass clonal propagation [10]. Since 1989, Klimaszewska has used the precotyledon IZEs of hybrid larch as explants to induce embryogenic tissues (ETs) on the medium supplemented with $2.0 \mathrm{mg} \cdot \mathrm{L}^{-1}$ 2,4-dichlorophenoxyacetic acid (2,4-D) and $0.5 \mathrm{mg} \cdot \mathrm{L}^{-1}$ 6-benzylaminopurine (6-BA), and further the greatest number of mature embryoids was obtained on MSG with $0.1 \mathrm{mg} \cdot \mathrm{L}^{-1}$ abscisic acid (ABA) and $0.2 \mathrm{mg} \cdot \mathrm{L}^{-1}$ kinetin (KT) [11]. Research on SE of larch is developing rapidly, L. decidua [12], L. laricina [13], L. occidentalis [14] and other larch have established an SE system and obtained regenerated plants. Fang et al. found that only immature zygotic embryos could induce ETs on the medium supplemented with $1.0 \mathrm{mg} \cdot \mathrm{L}^{-1} 2,4-\mathrm{D}, 0.5 \mathrm{mg} \cdot \mathrm{L}^{-1} 6$-BA and $0.5 \mathrm{mg} \cdot \mathrm{L}^{-1}$ KT by using immature embryos, mature embryos, radicle and Hypocotyl of Larix kaempferi as explants [15]. Song et al. reported that the embryos of L. olgensis seeds collected 70 days after open-pollination was suitable to induce ETs on basic BM medium containing $1.5 \mathrm{mg} \cdot \mathrm{L}^{-1}$ 2,4-D [16]. However, L. principis-rupprechtii Mayr. still lacks a mature and stable SE system. The application of SE of L. principis-rupprechtii Mayr. in practice is restricted by the low induction rate of embryogenic mass, the difficulty of maintaining embryogenic mass in proliferation and the low frequency of somatic embryos in maturation.

SE is usually influenced by multiple factors, such as genotype, culture methods, and phytohormones. Genotype is an intrinsic factor affecting SE. The average induction rate of embryonic callus of eight immature female gametophytes in Pinus yunnanensis is $5.1 \%-19.4 \%$, and genotypes 076 and 075 show the highest and lowest induction rate, respectively, suggesting that the genotype have significant influence on the induction of ETs [17]. At present, the common methods of plant somatic embryo culture include continuous liquid suspension culture, alternating solid/liquid culture and continuous solid culture [18]. Song et al. found that when optimizing the suspension culture system of larch ETs, the ETs were propagated through suspension culture, and a large number of highquality and uniformly dispersed ETs were obtained in a short time, then passed through a gradient of solid agar concentration, the number of somatic embryos was significantly increased in the final maturity induction [19]. ABA is considered to be a key factor to promote the somatic embryo maturation. Both endogenous ABA and exogenous ABA play important roles in somatic embryo development and maturation in many different coniferous species [2]. During the maturation of larch somatic embryos, it is often necessary to add a higher concentration of ABA [20]. Studies have found that the combined use of ABA, PEG4000 and $\mathrm{AgNO}_{3}$ can increase the efficiency of somatic embryos [21,22], but the induced somatic embryos still cannot develop normally [23]. Experiments have confirmed that the average number of L. olgensis somatic embryos was $202.06 \mathrm{~g}^{-1}$ when adding $20 \mathrm{mg} \mathrm{L}^{-1}$ ABA [24]. In Pinus koraiensis, increasing ABA (up to $80 \mu \mathrm{M} \mathrm{L}^{-1}$ ), gellan gum 
(up to $12 \mathrm{~g} \mathrm{~L}^{-1}$ ) and sucrose $\left(0.2 \mathrm{~m} \mathrm{~L}^{-1}\right)$ concentrations in maturation medium improved the yield of cotyledonary somatic embryo [25].

In view of the above-mentioned problems, this study addressed the optimization of the induction and proliferation of embryogenic mass and explored the conditions for the somatic embryos' development to improve the efficiency of SE in Prince Rupprecht's larch. This study provides technical support for optimizing and breaking through the difficulties of somatic embryo induction and low somatic embryo maturity in the existing SE system of Prince Rupprecht's larch. It lays a foundation for future application in largescale forestry production and provides ideal research materials for the study of somatic embryo generation mechanism and genetic transformation of conifers.

\section{Materials and Methods}

\subsection{Plant Materials}

The open-pollinated cones were collected from the L. principis-rupprechtii Mayr. seed orchard (Chengde, Hebei, China; latitude $117^{\circ} 21^{\prime} \mathrm{N}$, longitude: $42^{\circ} 27^{\prime} \mathrm{W}$, elevation $1200 \mathrm{~m}$ ). The collection date refers to our previous research results [26]. Immature cones of excellent individuals from 20 families were collected on 5 July 2013. All cones were sprayed with $75 \%$ $(w / v)$ alcohol for preliminary disinfection and dry with sterile filter paper and stored at $4{ }^{\circ} \mathrm{C}$ up to one month until inoculation. Megagametophytes containing immature zygotic embryos (IZEs) were used as explants for SE, including induction and proliferation of ETs, maturation and germination of somatic embryos and plant regeneration.

\subsection{Initiation of Embryogenic Tissues}

Immature seeds extracted from the cones were surface-disinfested by running water for $2 \mathrm{~h}$, immersion in $75 \%$ ethanol for $2 \mathrm{~min}$ and $0.1 \%$ mercury chloride solution $(w / v)$ for $8 \mathrm{~min}$, followed by rinsing 3-4 times with sterile distilled water. Seed coats were removed with tweezers and a scalpel and then megagametophytes containing the embryos were cultured on the semi-solid media described below. The medium and methods developed by Klimaszewska et al. [27], described by Litvay et al. [28], and optimized by Li et al. [26] were used for culture establishment. IZEs with the megametophytes were placed horizontally on modify Litvay medium (mLV) [28] supplemented with $30 \mathrm{~g} \mathrm{~L}^{-1}$ sucrose, $3 \mathrm{~g} \mathrm{~L}^{-1}$ phytagel (Sigma), $0.4 \mathrm{~g} \mathrm{~L}^{-1}$ hydrolyzed casein (Sigma), $0.5 \mathrm{~g} \mathrm{~L}^{-1}$ glutamine (Sigma), $2.0 \mathrm{mg} \mathrm{L}^{-1}$ 2,4-D (Sigma) and $1.0 \mathrm{mg} / \mathrm{L}$ 6-BA (Sigma). The $\mathrm{pH}$ was adjusted to 5.8 before autoclaving at $121^{\circ} \mathrm{C}$. Glutamine was filter-sterilized and added to the cooled medium, which was then dispensed at $25 \mathrm{~mL}$ per $90 \times 15 \mathrm{~mm}$ plastic Petri plate (RNase/DNase free, NEST). Ten explants were inoculated on culture medium of each Peri dish. After six weeks of dark culture at $24 \pm 1{ }^{\circ} \mathrm{C}$, callus and ETs were counted, and the induction rate of ETs was calculated.

\subsection{Embryogenic Tissues Proliferation}

The stable embryogenic cell line BFU-LC2-3 established in our laboratory was used as experimental material to study ETs proliferation. ETs were placed on proliferation in semi-solid medium and in liquid suspension medium, respectively. The proliferation in semi-solid medium was $1 / 2 \mathrm{mLV}$ medium supplemented with $30 \mathrm{~g} \mathrm{~L}^{-1}$ sucrose, $3 \mathrm{~g} \mathrm{~L}^{-1}$ phytagel (Sigma), $0.4 \mathrm{~g} \mathrm{~L}^{-1}$ hydrolyzed casein (Sigma), $0.5 \mathrm{~g} \mathrm{~L}^{-1}$ glutamine (Sigma), $0.2 \mathrm{mg} \mathrm{L}^{-1}$ 2,4-D (Sigma) and $0.1 \mathrm{mg} \mathrm{L}^{-1}$ 6-BA (Sigma). The proliferation rate of ETs was measured every three days, and callus growth was continuously monitored for 21 days in order to determine the optimal interval between subcultures.

Liquid suspension medium contains the same culture ingredients as solid culture medium, except for no gellan gum. Liquid culture medium of $30 \mathrm{~mL}$ was added to a $100 \mathrm{~mL}$ Erlenmeyer flask and the initial inoculating density was $2 \%(w / v)$. The flasks with ETs were placed on a gyratory shaker, $105 \mathrm{rpm}$, in darkness at $24 \pm 1{ }^{\circ} \mathrm{C}$. The ETs proliferation rate was measured every two days, and the growth of ETs was observed continuously for 12 days to determine the optimal time for subculture. For tissues subcultures, the large cell 
mass was removed by filtration through the filter of 60 or 100 mesh cells. After filtration, the culture solution was precipitated for 1-2 h. Supernatant was discarded before fresh liquid medium was added.

\subsection{Somatic Embryo Maturation}

The embryogenic cell line BFU-LC2-8 was used as the experimental material to study the somatic embryo maturation. Maturation of SE included two steps: transition stage and maturation stage. In the transition stage, the ETs were placed on $1 / 2 \mathrm{mLV}$ medium supplemented with $2 \mathrm{~g} \mathrm{~L}^{-1}$ active carbon (AC), $10 \mathrm{~g} \mathrm{~L}^{-1}$ sucrose, $0.4 \mathrm{~g} \mathrm{~L}^{-1}$ hydrolyzed casein and $0.5 \mathrm{~g} \mathrm{~L}^{-1}$ glutamine without plant growth regulators (PGRs). The cultures were kept in the dark, $24 \pm 1^{\circ} \mathrm{C}$ for 7 days.

\subsubsection{Effect of ABA on Somatic Embryo Production}

To explore the optimal concentration of ABA in the SE system of L. principis-rupprechtii Mayr., various concentrations of ABA were tested in the maturation stage, including 8 , 12, 16, 20 and $24 \mathrm{mg} \mathrm{L}^{-1}$. Moreover, $50 \mathrm{~g} \mathrm{~L}^{-1}$ PEG4000 (Sigma), $40 \mathrm{~g} \mathrm{~L}^{-1}$ sucrose, $5 \mathrm{~g} \mathrm{~L}^{-1}$ phytagel, $0.4 \mathrm{~g} \mathrm{~L}^{-1}$ hydrolyzed casein and $0.5 \mathrm{~g} \mathrm{~L}^{-1}$ glutamine were also supplemented in the maturation medium. The culture condition was as the same as the transition stage.

\subsubsection{Effect of Sucrose, Phytagel and PEG4000 on Somatic Embryo Production}

Here, an orthogonal experimental design $\mathrm{L}_{9}\left(3^{4}\right)$ was employed to detect the effects of sucrose, phytagel and PEG4000 on somatic embryo maturation. In the orthogonal experiment, the concentrations of sucrose, phytagel and PEG4000 were set as 30, 40 and $50 \mathrm{~g} \mathrm{~L}^{-1} ; 3,5,7 \mathrm{~g} \mathrm{~L}^{-1} ; 0,50$ and $75 \mathrm{~g} \mathrm{~L}^{-1}$, respectively. Moreover, $16 \mathrm{mg} \mathrm{L}^{-1} \mathrm{ABA}, 0.4 \mathrm{~g} \mathrm{~L}^{-1}$ hydrolyzed casein and $0.5 \mathrm{~g} \mathrm{~L}^{-1}$ glutamine were also supplemented in the maturation medium. About $1 \mathrm{~g}$ (fresh weight, FW) of ETs per petri dish was accurately weighed and spread evenly on the mature medium by pipetting.

Medium $\mathrm{pH}$ above was adjusted to 5.8. The culture was kept in the dark (at $24 \pm 1^{\circ} \mathrm{C}$ ). After 8 weeks, the number of mature embryos (cotyledon number $>5$ ) was counted and the maturation efficiency was calculated.

\subsubsection{Effect of Different Tissue Inoculation Methods on Somatic Embryo Production}

To study effects of different tissue inoculation methods on somatic embryo maturation, tissues were inoculated in pieces or in well-dispersed condition. The ETs were placed on 1/2 mLV medium supplemented with $16 \mathrm{mg} \mathrm{L}^{-1} \mathrm{ABA}, 50 \mathrm{~g} \mathrm{~L}^{-1}$ PEG4000, $40 \mathrm{~g} \mathrm{~L}^{-1}$ sucrose, $5 \mathrm{~g} \mathrm{~L}^{-1}$ gellan gum (phytagel), $0.4 \mathrm{~g} \mathrm{~L}^{-1}$ hydrolyzed casein and $0.5 \mathrm{~g} \mathrm{~L}^{-1}$ glutamine. Piece culture: the callus was accurately weighed (about $0.5 \mathrm{~g}$ per piece) and placed on the maturation medium. Dispersion culture: using proximate $1 \mathrm{~g}$ ETs and spreading it evenly on maturation medium by pipetting.

\subsection{Embryo Germination and Conversion}

Well-developed cotyledonary embryos were transferred to $1 / 2 \mathrm{mLV}$ medium containing $10 \mathrm{~g} \mathrm{~L}^{-1}$ sucrose, $3.2 \mathrm{~g} \mathrm{~L}^{-1}$ gellan gum (phytagel), 0, 1, 2, 3, $4 \mathrm{~g} \mathrm{~L}^{-1}$ activated carbon, $0.5 \mathrm{~g} \mathrm{~L}^{-1} \mathrm{NH}_{4} \mathrm{NO}_{3}, 0.5 \mathrm{~g} \mathrm{~L}^{-1}$ glutamine under light (16-h photoperiod) or dark conditions at $24 \pm 1{ }^{\circ} \mathrm{C}$. Medium PH was adjusted to 5.8. Selected embryos of 16 32 were cultured in each Petri dish. The germination rate was calculated after 40 days. After the cotyledonary embryos seedlings elongated and the root grew over $2 \mathrm{~cm}$, the cap of culture bottle was open for 2-3 days before the plants were transplanted. A total of 90 somatic seedlings were removed from the tissue culture bottle. The plants were washed gently to clean the culture medium from roots before transplanted into a container filled with a mixture of (sterilized peat:perlite:roseite $=2: 1: 1$ ). The containers with plants were covered with transparent plastic film to keep humidity and placed under light (16 h photoperiod) or dark, at $23 \pm 1^{\circ} \mathrm{C}$. After eight weeks, the plastic film was removed and the transplant survival rate was calculated. 


\subsection{Experiment Design and Data Analysis}

All experiments were performed with three replicates, with 7 10 pieces per Peri dish. Additionally, all collected data were analyzed with Excel 2010 or SPSS 20.0. All frequencies were calculated using the below formulas:

Embryogenic tissues induction rate $(\%)=($ Explants number of ETs induced $/$ Number of explants inoculated $) \times 100 \%$

SE maturation efficiency (No. of SE/g) = Number of somatic embryos differentiated / fresh weight of inoculated ETs Germination rate $(\%)=($ Number of germinated somatic embryos/Number of somatic embryos inoculated $) \times 100 \%$ soil establishment rate of transplant $(\%)=$ (Number of survival plants transplanted/Total number of transplanted plants) $\times 100 \%$

All collected data was tested by analysis of variance (ANOVA) using statistical programming environment R. Significant differences between means were identified using Tukey's HSD (honestly significant difference) test at a significance level of 5\%.

\section{Results}

\subsection{Embryogenic Tissues Initiation}

After inoculating explants in the induction medium, we observed a continuous induction of ETs, which could be classified into four types (Figure 1). The first type involved white and transparent tissues extruded from the micropyle of the female gametophyte (Figure 1a). These ETs could be easily separated from the explants after approximately half a month of subculture. The second type involved tissues that were initially brown, and after 1-2 subcultures, new ETs gradually grew on the surface of the brown tissues (Figure 1b). The third type of ETs exhibited delayed induction, appearing as loose, moist, brown tissues in the early induction period. After 2-3 months, new white translucent ETs gradually grew; these new tissues could not be easily separated from the surrounding tissues (Figure 1c). New ETs were also induced from the moist, brown tissues. The fourth type involved yellow-brown, hard, dense, non-embryogenic tissues (NETs), which could not generate new ETs (Figure 1d).
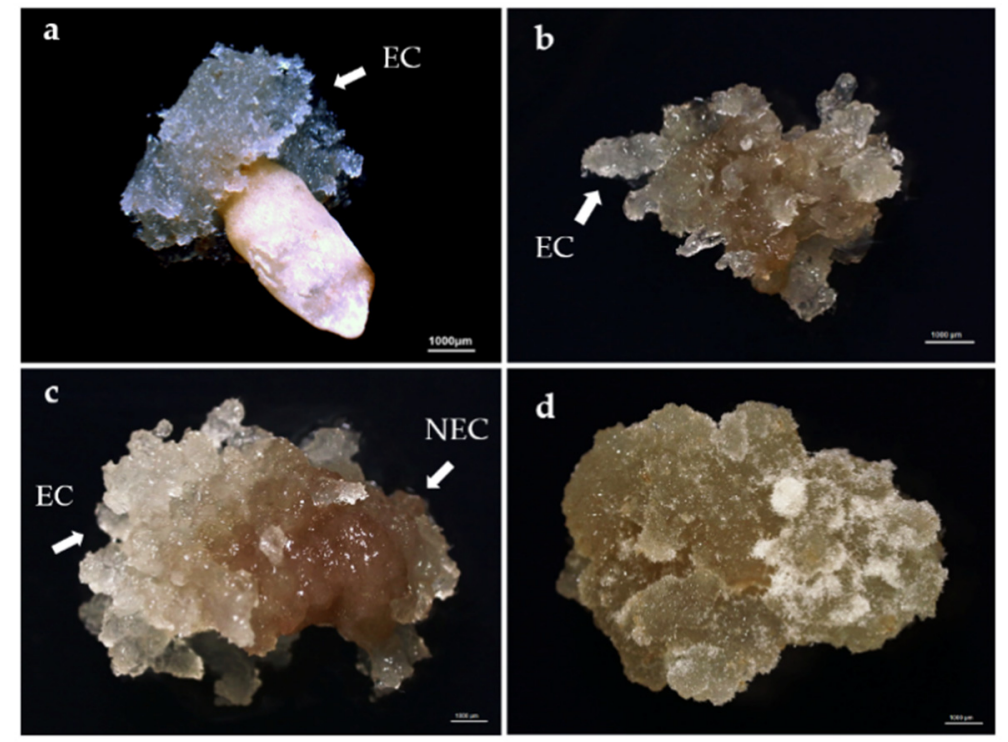

Figure 1. Tissues induction of L. principis-rupprechtii Mayr. (a) ETs extruded from micropyle. (b) ETs induced from brown tissues. (c) ETs induced from one side of loose brown NETs. (d) Yellow and brown non-ETs. Bars $=1000 \mu \mathrm{m}$.

The induction from explants of 20 Larch families showed that the genotype of the explants was critical in the SE initiation. The induction rate in these 20 families ranged 
between $0 \%$ and $30.0 \%$. The highest induction rate (30.0\%) was observed in families 23 and 25, and the induction of only NETs was observed in families 7 and 14 (Table 1).

Table 1. Effects of mother trees on ETs induction in L. principis-rupprechtii Mayr.

\begin{tabular}{ccccc}
\hline $\begin{array}{c}\text { Mother Tree } \\
\text { No. }\end{array}$ & $\begin{array}{c}\text { Number of } \\
\text { Explants }\end{array}$ & $\begin{array}{c}\text { Number of } \\
\text { Callus }\end{array}$ & $\begin{array}{c}\text { Number of } \\
\text { ETs }\end{array}$ & $\begin{array}{c}\text { Initiation Frequency } \\
\mathbf{( \% )}\end{array}$ \\
\hline 2 & 50 & 32 & 6 & $12.0 \pm 13.0 \mathrm{abc}$ \\
4 & 50 & 21 & 2 & $4.0 \pm 5.5 \mathrm{ab}$ \\
7 & 50 & 35 & 0 & $0 \mathrm{a}$ \\
8 & 50 & 13 & 1 & $2.0 \pm 4.5 \mathrm{a}$ \\
10 & 50 & 40 & 10 & $20.0 \pm 18.7 \mathrm{bcd}$ \\
14 & 50 & 35 & 0 & $0 \mathrm{a}$ \\
15 & 50 & 10 & 1 & $2.0 \pm 4.5 \mathrm{a}$ \\
18 & 50 & 26 & 3 & $16.0 \pm 11.4 \mathrm{abcd}$ \\
19 & 50 & 17 & 5 & $6.0 \pm 9.0 \mathrm{ab}$ \\
20 & 50 & 42 & 15 & $10.0 \pm 7.1 \mathrm{abc}$ \\
23 & 50 & 38 & 7 & $30.0 \pm 14.1 \mathrm{~d}$ \\
25 & 50 & 19 & 10 & $30.0 \pm 7.1 \mathrm{~d}$ \\
28 & 55 & 2 & $14.0 \pm 5.5 \mathrm{abc}$ \\
29 & 50 & 8 & $20.0 \pm 10.0 \mathrm{bcd}$ \\
31 & 50 & $6.0 \pm 5.5 \mathrm{ab}$ \\
32 & 50 & 6 & $16.0 \pm 9.0 \mathrm{abcd}$ \\
35 & 50 & 17 & 13 & $12.0 \pm 16.4 \mathrm{abc}$ \\
38 & 50 & 26 & 13 & $4.0 \pm 9.0 \mathrm{ab}$ \\
39 & 50 & 38 & $26.0 \pm 15.2 \mathrm{~cd}$ \\
40 & 50 & 21 & $26.0 \pm 13.9 \mathrm{~cd}$ \\
\hline
\end{tabular}

Note: Date represented the mean of initiation frequency of all replicates. Lowercase letters represent the result of multiple comparisons, means having the same letter were not significantly different by Tukey's multiple range test $(p \leq 0.05)$. ETs, embryogenic tissues.

\subsection{Embryogenic Tissues Proliferation}

The ETs were transferred to the proliferation in semi-solid medium after being subcultured twice on the induction medium. The large ETs on the semi-solid culture were white and translucent, with tiny filamentous structures (Figure 2a). The proliferation rate of ETs on proliferation in semi-solid medium culture was relatively stable, without significant fluctuations. The proliferation coefficient reached 2.53 on day 15 and then decreased slightly (Figure 2c). The ETs turned to brown gradually after 15 days. Therefore, the ideal subculture period of semi-solid culture was determined to be approximately 15 days.

An ETs suspension system was established (Figure 2b). Growth of embryonic cells in suspension culture showed an S-type curve (Figure 2d). At the initial stage of proliferation, the cell proliferation rate was relatively high. However, with the depletion of nutrients, the tissues proliferation in suspension culture reached an inflection point and leveled off 8 days later when the cell proliferation coefficient was 3.12. Subsequently, the cell proliferation rate significantly decreased. Additionally, browning cells began to appear in the suspension after 7 days, which was not conducive to further proliferation and subsequent culture for embryo maturation. Therefore, the optimal subculture interval for suspension culture was determined to be $7-8$ days. 


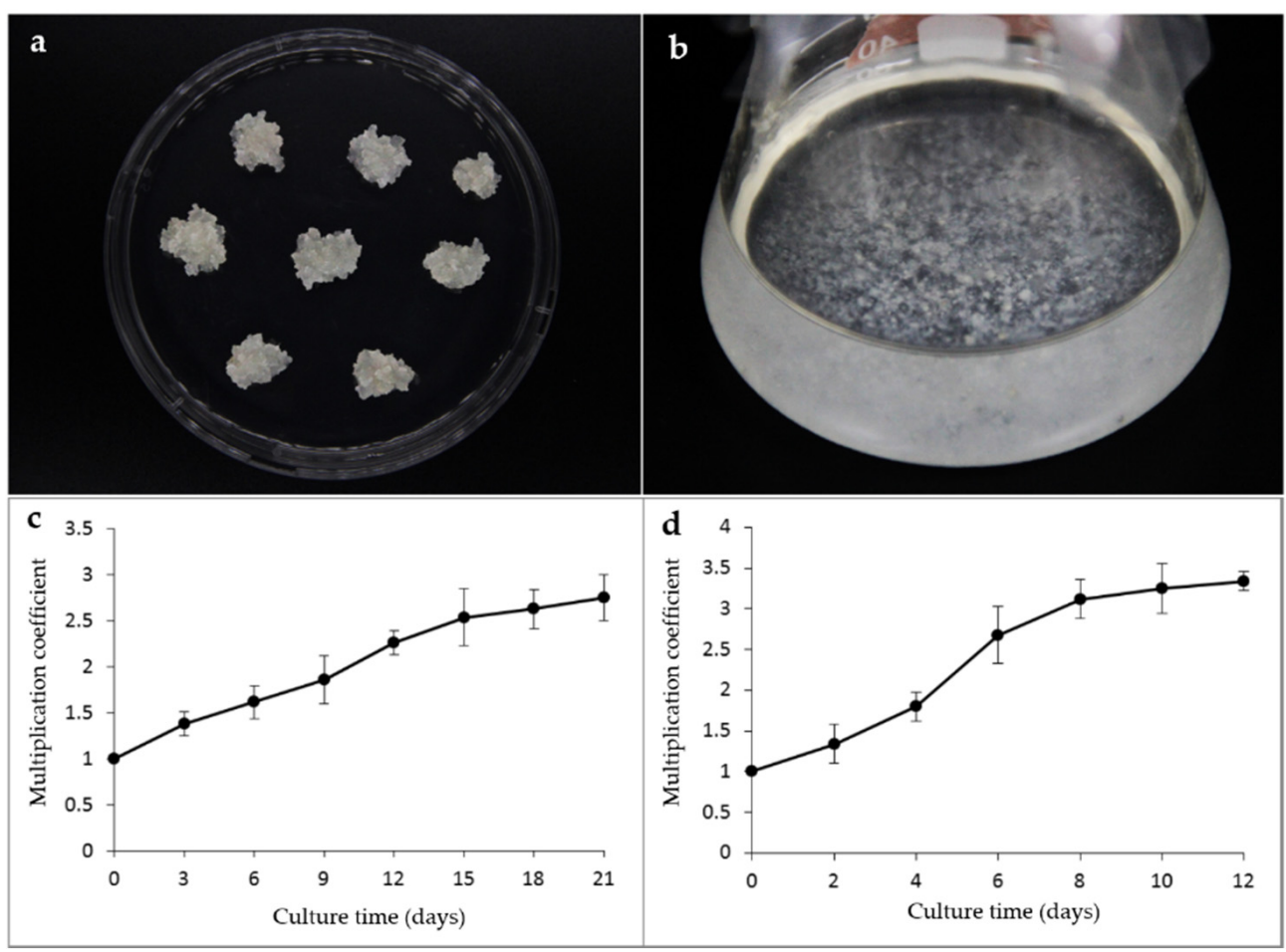

Figure 2. Growth curve of embryogenic lines in two proliferation ways. (a,c) Proliferation in semisolid medium. (b,d) Proliferation in liquid medium.

\subsection{Somatic Embryo Maturation}

About 1-3 weeks after the initial inoculation, proembryogenic mass (PEM) was formed. The PEM I embryo proper was composed of a few cells with large dense nuclei and the suspensor was composed of only 1-3 vacuolar suspensor cells (Figure 3a). With further growth of PEM, PEM II structures were formed, in which cell aggregation increased in the embryo proper and suspensor (Figure $3 b$ ). Somatic embryos of PEM III were suitable to be cultured on maturation medium containing ABA (Figure 3c). After maturation culture, somatic embryos developed into cotyledonary embryos through early proembryo, globular, and torpedo-shaped stages successively.

\subsubsection{Effects of ABA on Somatic Embryo Maturation}

The number of somatic embryos per gram (FW) of ETs was different in various ABAsupplemented maturation treatments. Compared with other treatments, 16 and $20 \mathrm{mg} \mathrm{L}^{-1}$ ABA could promote somatic embryo maturation more effectively with the yield of 222 and 216 embryos per gram (FW), respectively. However, no significant differences $(p>0.05)$ were observed between 16 and $20 \mathrm{mg} \mathrm{L}^{-1}$ of ABA (Figure 4a). Therefore, $16 \mathrm{mg} \mathrm{L}^{-1}$ of $\mathrm{ABA}$ was deemed the optimal ABA concentration for somatic embryo maturation.

\subsubsection{Effects of Culture Methods on Somatic Embryo Maturation}

We found significant differences in somatic embryo maturation between piece culture (Figure 3f,g) and dispersion culture (Figure 3d,e). On average, 124 mature somatic embryos per gram (FW) of ETs were produced in piece culture, while this number in dispersion culture was 545 (Figure $4 \mathrm{~b}$ ). Therefore, the higher efficiency of the dispersion culture in somatic embryo maturation might be attributed to the easier absorption of nutrients by the tissues. 


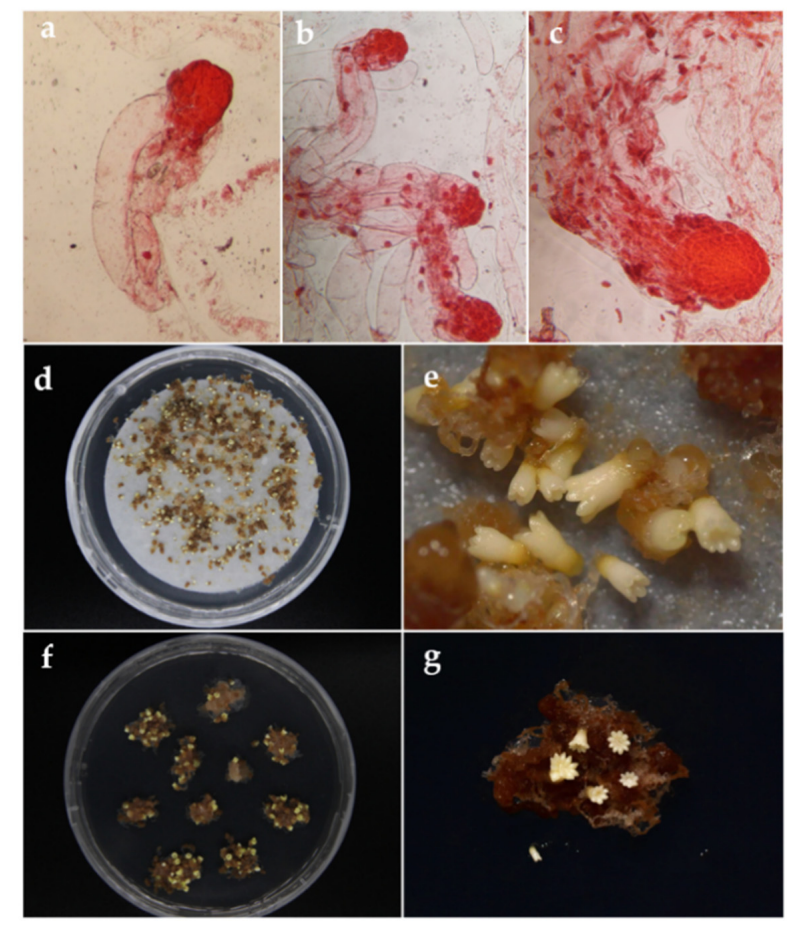

Figure 3. Somatic embryo maturation in L. principis-rupprechtii Mayr. (a) PEM I. (b) PEM II. (c) PEM III. (d,e) Dispersion culture. (f,g) Piece culture. Bars a, b, c = $50 \mu \mathrm{m}, \mathrm{e}=500 \mu \mathrm{m}, \mathrm{g}=1000 \mu \mathrm{m}$.

$\mathbf{a}$

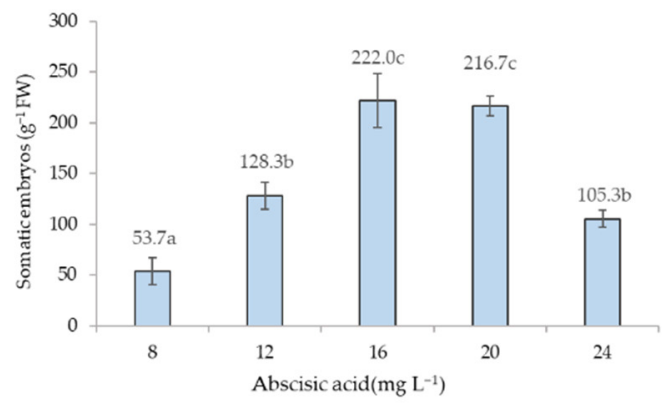

b

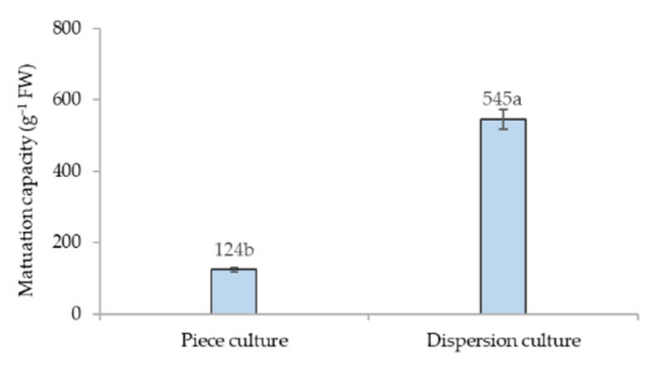

Figure 4. (a) Effects of different concentrations of ABA on somatic embryo maturation in L. principis-rupprechtii Mayr. (b) Effects of different culture approaches on somatic embryo maturation. FW, fresh weight.

\subsubsection{Effects of Sucrose, Gellan Gum (phytagel) and PEG on Somatic Embryo Maturation}

The effects of different levels of sucrose, gellan gum (phytagel) and PEG supplemented to maturation culture on L. principis-rupprechtii Mayr. embryos maturation was investigated. All of the three factors showed significant effects on SE maturation by ANOVA (Table 2). Multiple comparison results showed that there was no significant difference between treatments with 40 and $50 \mathrm{~g} \mathrm{~L}^{-1}$ sucrose. However, treatment with $50 \mathrm{~g} \mathrm{~L}^{-1}$ sucrose produced the highest number of somatic embryos per gram (FW) of ETs $\left(173 \mathrm{~g}^{-1}\right)$. Statistical difference was found between different concentrations of gellan gum (phytagel). Furthermore, the number of somatic embryos per gram of ETs reached the maximum number $\left(192 \mathrm{~g}^{-1}\right)$ when the medium was supplemented with $7 \mathrm{~g} \mathrm{~L}^{-1}$ gellan gum (phytagel). In addition, a high number of somatic embryos $\left(185 \mathrm{~g}^{-1}\right)$ were obtained when treated with $75 \mathrm{~g} \mathrm{~L}^{-1}$ PEG. The orthogonal experiment results showed that the optimum conditions for somatic embryo maturation were $50 \mathrm{~g} \mathrm{~L}^{-1}$ sucrose, $7 \mathrm{~g} \mathrm{~L}^{-1}$ gellan gum (phytagel) and $75 \mathrm{~g} \mathrm{~L}^{-1}$ PEG, which indicated that maturation of larch requires a hypertonic environment (Table 3). 
Table 2. Analysis of variance (ANOVA) of effect of sucrose, gellan gum (phytagel) and PEG on somatic embryo maturation.

\begin{tabular}{ccccc}
\hline $\begin{array}{c}\text { Source of } \\
\text { Variation }\end{array}$ & df & Mean Square & F Value & Sig. \\
\hline sucrose & 2 & 6540.704 & 64.516 & $0.000^{* *}$ \\
phytagel & 2 & 24581.815 & 242.468 & $0.000^{* *}$ \\
PEG & 2 & 6572.259 & 64.827 & $0.000^{* *}$ \\
Error & 20 & 101.381 & & \\
\hline
\end{tabular}

Table 3. Multiple comparison of effect of sucrose, phytagel and PEG on somatic embryo maturation.

\begin{tabular}{|c|c|c|c|c|c|c|c|c|c|}
\hline $\begin{array}{l}\text { Levels } \\
\text { of } \\
\text { Factors }\end{array}$ & $\begin{array}{c}\text { Sucrose } \\
(\mathrm{g} / \mathrm{L})\end{array}$ & $\begin{array}{c}\text { Mean Value } \\
\text { of Somatic } \\
\text { Embryos } \\
\left(\mathrm{g}^{-1} \text { FW) }\right.\end{array}$ & $\begin{array}{l}\text { Sig. of } \\
\text { Differ- } \\
\text { ence }\end{array}$ & $\begin{array}{l}\text { Gellan } \\
\text { Gum } \\
(\mathrm{g} / \mathrm{L})\end{array}$ & $\begin{array}{c}\text { Mean Value } \\
\text { of Somatic } \\
\text { Embryos } \\
\left(\mathrm{g}^{-1} \text { FW) }\right.\end{array}$ & $\begin{array}{l}\text { Sig. of } \\
\text { Differ- } \\
\text { ence }\end{array}$ & $\begin{array}{l}\text { PEG } \\
\text { (g/L) }\end{array}$ & $\begin{array}{c}\text { Mean } \\
\text { Value of } \\
\text { Somatic } \\
\text { Embryos } \\
\left(g^{-1} \text { FW) }\right.\end{array}$ & $\begin{array}{l}\text { Sig. of } \\
\text { Differ- } \\
\text { ence }\end{array}$ \\
\hline 1 & 30 & 123.7778 & $\mathrm{Aa}$ & 3 & 95.0000 & $\mathrm{Aa}$ & 0 & 137.5556 & $\mathrm{Aa}$ \\
\hline 2 & 40 & 167.4444 & $\mathrm{Bb}$ & 5 & 177.2222 & $\mathrm{Bb}$ & 50 & 140.7778 & $\mathrm{Aa}$ \\
\hline 3 & 50 & 173.0000 & $\mathrm{Bb}$ & 7 & 192.0000 & $\mathrm{Cc}$ & 75 & 185.8889 & $\mathrm{Bb}$ \\
\hline
\end{tabular}

Note: Different uppercase letters represent significant differences at $p \leq 0.01$, and different lowercase letters represent significant differences at $p \leq 0.05$. PEG, polyethylene glycol. FW, fresh weight.

\subsubsection{Somatic Embryo Germination and Conversion}

Well-developed cotyledonary embryos were selected and transferred to germination medium (Figure 5a). After 10 days, the cotyledons turned bright green, opened and gradually elongated (Figure $5 b$ ). The hypocotyl elongated and the red root tip appeared at the apical part of the radicle. The cotyledons with abnormal germination might turn green and open slightly, but the hypocotyl was swollen and could not generate roots. Approximately one month later, radicles with a normal morphological structure elongated gradually, reaching 1-2 cm, and the root tips showed active red color (Figure 5c). Somatic embryos that germinated normally were converted into plants through acclimatization and were transferred onto a sterilized substrate (Figure $5 \mathrm{~d}-\mathrm{f}$ ).

The highest germination rate was obtained using the germination medium supplemented with $2(63.46 \%)$ and $3 \mathrm{~g} \mathrm{~L}^{-1}(61.13 \%) \mathrm{AC}$, with no significant difference (Figure 6). By contrast, germination rate was only $33.77 \%$ in the culture without $\mathrm{AC}$, indicating that AC with appropriate concentration was beneficial for somatic embryo germination. After 12 weeks of growth in a greenhouse, the survival rate of plantlet conversion was $26.67 \%$.

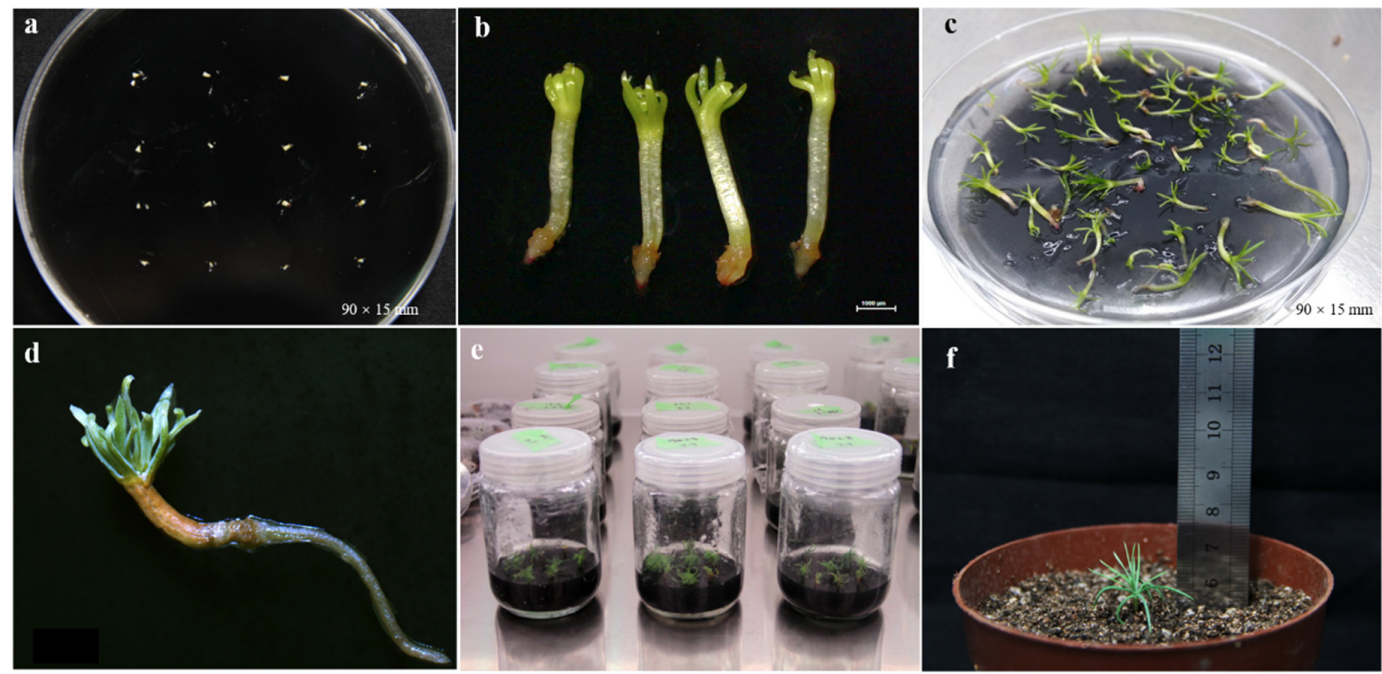

Figure 5. Somatic embryo germination and plant conversion in L. principis-rupprechtii Mayr. (a-c) Germination. (d-f) Conversion. Bars a, $\mathrm{c}=90 \times 15 \mathrm{~mm}, \mathrm{~b}, \mathrm{~d}=1000 \mu \mathrm{m}$. 


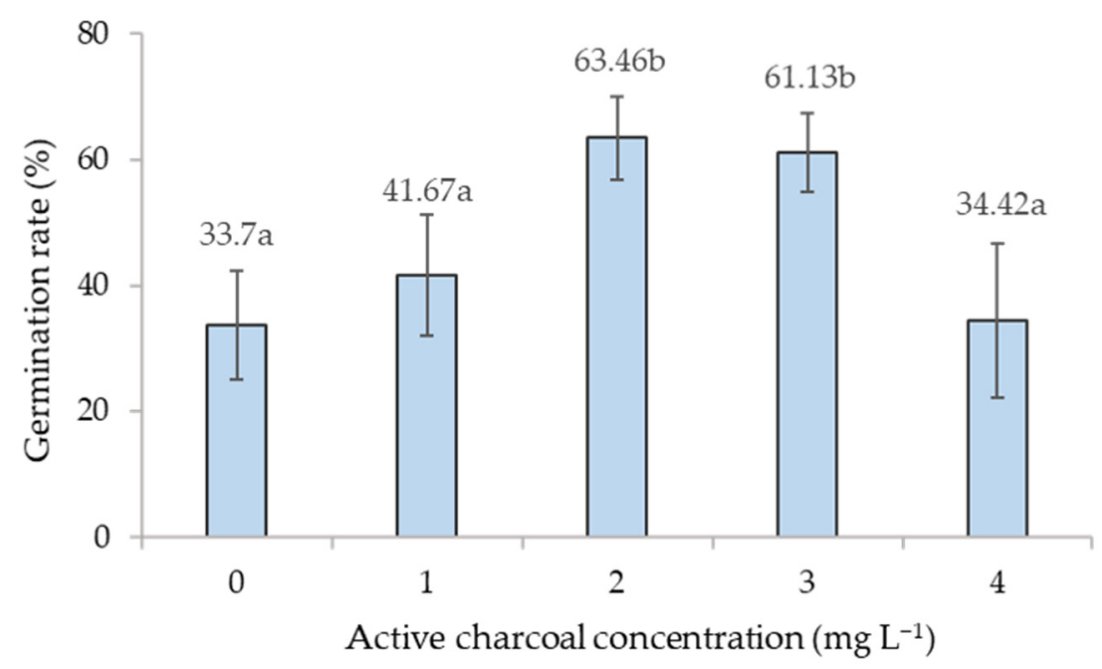

Figure 6. Effects of active charcoal on somatic embryo germination.

\section{Discussion}

\subsection{Embryogenic Tissues Induction and Proliferation in L. principis-rupprechtii Mayr}

The induction of ETs is an important prerequisite for SE of conifers. The ETs are an ideal material for germplasm conservation, genetic transformation and cell fusion [29,30]. In this study, the universality of the application of culture condition in previous study was verified. We tested various ETs induction conditions in 20 different L. principis-rupprechtii Mayr. families. We observed a high ETs induction efficiency in most families, with the highest ETs induction rate being approximately 30\%. However, in some L. principisrupprechtii Mayr. families, no ETs induction was observed. These findings were consistent with previous findings in conifers. In Picea omorica, the highest ETs induction frequency of five cultivars was $18.7 \%$, while the lowest was $1.3 \%$, despite identical explant size and culture conditions. Similar ETs induction rates have been reported for mature embryos of seven Picea likiangensis (Franch.) Pritz families. The ETs induction rate varied among the different families under the same culture conditions, with a maximum of $41.3 \%$ and a minimum of $0.7 \%$ [31].

These results highlighted that genotype strongly affects the ETs initiation rate, which was common in studies on SE of conifers [32,33]. Our results showed that the conditions of ETs initiation needed to be screened to obtain suitable culture conditions for most genotypes of a certain conifer at first. Further screening of culture conditions was carried out for individual genotypes, especially for those with good performance, which was very valuable for reference in future studies of SE.

Rapid proliferation of the ETs is critical for the large-scale production of somatic seedlings. Compared with proliferation in semi-solid medium, proliferation in liquid medium systems typically provide faster growth, less variability, easy visual observation, and automatic transfer of cell suspension [34]. We found that the proliferation efficiency of liquid suspension culture (3.12/8 days) was significantly higher than that of semi-solid culture (2.53/15 days), indicating that the amount of nutrients absorbed by ETs in semisolid and liquid medium differed, possibly due to differences in diffusion rates between the different medium types $[35,36]$. Therefore, optimizing the liquid culture conditions is the key to improving the yield of L. principis-rupprechtii Mayr. SE.

\subsection{Somatic Embryo Maturation}

Various factors influence the somatic embryo maturation. Numerous studies have shown that modulating the osmotic pressure and ABA concentration in the maturation medium greatly affects somatic embryo maturation in conifers [20,37]. The primary function of $\mathrm{ABA}$ is to prevent cleavage polyembryos and promote the maturation of single embryos [37]. Here, we found that the optimal ABA concentration for somatic embryo 
formation was $16 \mathrm{mg} \mathrm{L}^{-1}$, and 222 embryos per gram (FW) of ETs were obtained. Although ABA was widely used in somatic embryo maturation culture in conifers, the optimal ABA concentration varies among different conifer species. For example, the optimal ABA concentration for somatic embryo maturation of Podocarpus lambertii Klotzsch ex Endl was $75 \mu \mathrm{M}$ [38], while that of western larch was only $0.025 \mu \mathrm{M}$, much lower than that of most conifers [14]. Qi et al. [39] adopted the optimal regression design of 311-A and found that the optimal ABA concentration for somatic embryo maturation in L. principis-rupprechtii Mayr was $18.91 \mathrm{mg} \mathrm{L}^{-1}$.

Somatic embryo maturation is typically augmented by high osmotic pressure in the medium. Low water availability activates ABA-mediated molecular and physiological responses to promote embryonic development [40]. There are two main ways to improve osmotic pressure. The first is by adding sucrose, maltose, sugar, alcohol, PEG, or a combination of osmotic regulators in the medium to lower the water potential for osmotic pressure regulation [41]. The second approach is to increase the concentration of gelling agents in the maturation medium, thereby enhancing gel strength and reducing the available water in the medium, ultimately promoting somatic embryo maturation $[42,43]$.

In our study, treatment with $50 \mathrm{~g} \mathrm{~L}^{-1}$ sucrose produced the highest number of somatic embryos per gram (FW) of ETs $\left(173 \mathrm{~g}^{-1}\right)$. Similarly, the high osmotic pressure induced by sucrose facilitates somatic embryo and maturation in conifers, including Pinus yunnanensisi, Picea wilsonii Mast., Picea meyeri, L. kaempferi $[15,44]$. We also found that different concentrations of gellan gum (phytagel) results in statistical difference. The number of somatic embryos per gram (FW) of ETs $\left(192 \mathrm{~g}^{-1}\right)$ was highest when the medium was supplemented with $7 \mathrm{~g} \mathrm{~L}^{-1}$ gellan gum (phytagel). Increasing the concentration of gellan gum in the maturation medium significantly improved the quantity and quality of somatic embryos in Pinaceae species, including P. strobus, P. pinaster, P. sylvestris, P. luchuensis Mayr, P. thunbergii Parl., P. densiflora Zieb. et Zucc. and hybrid larch, etc. [45-47]. Studies have also shown that increasing the concentration of gellan gum from 4 to $8 \mathrm{~g} \mathrm{~L}^{-1}$ significantly enhanced the production of hybrid Larch cotyledonary embryos, the survival rate of whom was profoundly higher after germination. Increasing the concentration of gellan gum in the medium increased somatic embryo dry weight, whereas the water content decreased, resulting in culture conditions resembling partial desiccation [48]. Similarly, suitable PEG concentrations induce osmotic stress in cells, similar to that under drought conditions, increasing the concentration of cell inclusions and facilitating the development of somatic embryos [49]. PEG is one of the most commonly used osmotic regulators in somatic embryo, particularly in conifers. In our study, a high number of somatic embryos $\left(185 \mathrm{~g}^{-1}\right)$ were obtained when treated with PEG $\left(75 \mathrm{~g} \mathrm{~L}^{-1}\right)$.

Numerous studies have shown that ABA combined with a high concentration of PEG, sucrose, and gellan gum significantly improved the quantity and quality of mature somatic embryos in conifers $[35,50,51]$. In this study, we identified the optimal concentrations of sucrose, gellan gum (phytagel), and PEG in the maturation medium. The finding that high concentrations of these agents enhanced somatic embryo maturation is consistent with previous findings showing that high osmotic pressure facilitates somatic embryo maturation. However, since the optimal concentration was the highest concentration tested, future studies are required to assess the effects of even higher concentrations of sucrose, gellan gum (phytagel), and PEG. Additionally, future studies are required to determine the optimal embryo maturation conditions for different L. principis-rupprechtii Mayr genotypes. We also obtained more somatic embryos in dispersion culture than in piece culture. Therefore, it is expected that more somatic embryos will be obtained in dispersion culture under optimized conditions, which is likely to be higher than 222 somatic embryos per gram of fresh weight. The somatic embryo maturation rate achieved in our study was relatively higher than those reported in other larch species [19,23]. However, the effects of sucrose, phytagel, and PEG on somatic embryo germination, and subsequent plant growth should also be investigated. 


\subsection{Effect of Active Charcoal on Somatic Embryo Germination}

To improve somatic embryo germination and plant conversion rates, we optimized the culture conditions for germination and conversion, as well as pretreated embryos with AC before germination. AC supplementation has a beneficial effect on somatic embryo germination. Therefore, the addition of $\mathrm{AC}$ in the culture medium is common for the germination of somatic embryos in many conifers, including Pinus nigra, P. densiflora and $P$. armandii, etc. [52-54]. By contrast, common germination media for P. strobus and P. pinaster do not contain AC [55,56].

In this study, we found that $\mathrm{AC}$ at $2 \mathrm{~g} \mathrm{~L}^{-1}$ promoted somatic embryo germination in $L$. principis-rupprechtii Mayr. Compared with the absence of AC from the culture medium, the germination rate was significantly increased by $30 \%$ in the presence of $2 \mathrm{~g} \mathrm{~L}^{-1} \mathrm{AC}$. Similarly, the beneficial effect of $\mathrm{AC}$ has been widely reported in other conifer trees $[57,58]$. However, the effect of $\mathrm{AC}$ on somatic embryo germination and underlying mechanisms remain poorly understood. It is generally believed that AC promotes somatic embryo germination by modulating the concentration of various plant growth regulators, plant metabolic wastes, and toxic metabolites present in the culture medium (e.g., phenolic compounds and ethylene) [59-61]. Van Winkle et al. believe that the role of activated carbon in pine tissue culture is mainly in its absorption of phenolic acids and residual hormones [62]. It is worth noting that AC may also absorb medium components essential for plant growth, including plant growth regulators, vitamins, and ions (e.g., $\left.\mathrm{Cu}^{2+}, \mathrm{Zn}^{2+}\right)$, as well as alter the $\mathrm{pH}$ of the medium $[35,59,63]$. Therefore, we speculate that AC may absorb various components in the medium simultaneously, including beneficial and harmful components for somatic embryo germination. We believe that the accumulation of excessive hormones during somatic embryo maturation, such as $\mathrm{ABA}$, is the more important factor hindering the somatic embryos germination, and absorption of corresponding components can theoretically significantly promote somatic embryo germination. Comparatively, the absorption of the basic components of the medium had little effect on somatic embryo germination. Therefore, in general, the positive effect of appropriate AC on somatic embryo germination is greater than the negative effect. Therefore, it is necessary to elucidate the role of $A C$ and establish the optimal AC concentration in the culture medium to enhance the efficiency of somatic embryo germination.

\subsection{Effect of Physical Post-Maturation Treatment on Somatic Embryo Germination}

In general, physical treatment (e.g., drying and low-temperature exposure) of cotyledonary embryos before germination can improve somatic embryo germination and plant regeneration rates $[64,65]$. Drying is related to the degree of somatic embryo maturation, accumulation of stored substances and endogenous hormones, and the tolerance of somatic embryos to dehydration stress [66-71]. Low-temperature exposure can also improve somatic embryo germination and plant regeneration rates to a certain extent. The germination rate of Taiwan spruce somatic embryos reached $69.9 \%$ after the combination of $4{ }^{\circ} \mathrm{C}$ exposure for 3 weeks and slow drying for 7 days [72]. Additionally, 1 or 2 months of embryo storage on germination medium at $4{ }^{\circ} \mathrm{C}$ (stratification) significantly improved germination in Fraser fir [73].

To the best of our knowledge, there are no reports on the pretreatment of L. principisrupprechtii Mayr before somatic embryo germination. Thus, future studies are required to systematically investigate the influence of different drying treatments and low-temperature exposure on somatic embryo germination and plant transformation. The establishment of optimal pretreatment protocols will enable us to improve the conversion frequency of somatic seedlings and lay the foundations for the wider application of somatic embryo technologies in large-scale tree production. 


\section{Conclusions}

In summary, this article has improved the culture conditions of the ETs induction, proliferation, maturation and germination stages of Larix principis-rupprechtii Mayr. The reproduction coefficient of the system is improved, but the survival rate of plants after transplanting is still low, which limits the application of micropropagation in practice. In the future, we will further explore ways to improve the germination efficiency of somatic embryos by studying the pretreatment of somatic embryo germination, and obtain efficient survival approaches of somatic embryo seedlings by using mini-plug seedling, humidity gradient control and other methods, so as to establish a technical system of large-scale production of somatic embryo seedlings.

Author Contributions: S.J. and X.C. contributed to the manuscript writing. Conceived and designed the experiments: J.Z. (Jian Zhao), J.Z. (Jinfeng Zhang), S.J. and X.C. Performed the experiments: S.J. and X.C. Analyzed the data: S.J. and X.C. Contributed reagents/materials/analysis tools: Y.G. and Y.C. Writing_-original draft preparation: S.J. and X.C. Writing—review and editing: L.K. and J.Z. (Jian Zhao). All authors have read and agreed to the published version of the manuscript.

Funding: This research was funded by the Fundamental Research Funds for the Central Universities (BLX2015-14), the National Natural Science Foundation of China (31901289), State Key Laboratory of Tree Genetics and Breeding (K2018202), the project fund (Somatic embryogenesis and high efficient propagation technology in trees) provided by Beijing Advanced Innovation Center for Tree Breeding by Molecular Design, Key R\&D Program of Heibei Province, China (20326333D).

Institutional Review Board Statement: Not Applicable.

Informed Consent Statement: Not Applicable.

Data Availability Statement: Not Applicable.

Acknowledgments: We would like to specially thank Dan Li from Southwest Forestry University of China for her foundational exploration work in this SE system and Deshui Yuan from the National Key Seed Base of Larch, Weichang, Chengde, China, for his great contribution to mother trees selection and cones collection.

Conflicts of Interest: The authors declare no conflict of interest.

\section{References}

1. Wen, X.; Sun, Z.; Sun, S. A study on geographic distribution and population variation law of Larix principis-rupprechtii Mary. Nat. For. Shanxi Sci. Silvae Sin. 1992, 28, 493-501.

2. Ahn, C.H.; Tull, A.R.; Montello, P.M.; Merkle, S.A. A clonal propagation system for Atlantic white cedar (Chamaecyparis thyoides) via somatic embryogenesis without the use of plant growth regulators. Plant Cell Tissue Organ Cult. 2017, 130, 91-101. [CrossRef]

3. Rihan, H.Z.; Kareem, F.; El-Mahrouk, M.E.; Fuller, M.P. Artificial Seeds (Principle, Aspects and Applications). Agronomy 2017, 7, 71. [CrossRef]

4. Williams, E.G.; Maheswaran, G. Somatic embryogenesis: Factors influencing coordinated behaviour of cells as an embryogenic group. Ann. Botany 1986, 4, 443-462. [CrossRef]

5. Wang, F.X.; Shang, G.D.; Wu, L.Y.; Xu, G.Z.; Zhao, X.Y.; Wang, J.W. Chromatin Accessibility Dynamics and a Hierarchical Transcriptional Regulatory Network Structure for Plant Somatic Embryogenesis. Dev. Cell. 2020, 54, 742-757. [CrossRef]

6. Montalbán, I.A.; García-Mendiguren, O.; Moncaleán, P. Somatic Embryogenesis in Pinus sp. Methods Mol. Biol. 2016, 1359, 405-415.

7. Hakman, I.; Fowke, L.C.; Von Arnold, S. The development of somatic embryos in tissue cultures initiated from immature embryos of Picea abies (Norway Spruce). Plant Sci. 1985, 38, 53-59. [CrossRef]

8. Pullman, G.S.; Bucalo, K. Pine Somatic Embryogenesis Using Zygotic Embryos as Explants. Methods Mol. Biol. 2010, 267-291. [CrossRef]

9. Bettinger, P.; Clutter, M.; Siry, J.; Kane, M.; Pait, J. Broad implications of southern pine clonal forestry on planning and management of forests. Int. For. Rev. 2009, 11, 331-345. [CrossRef]

10. Gupta, P.K.; Timmis, R. Mass propagation of conifer trees in liquid cultures-progress toward commercialization. Plant Cell Tissue Organ Cult. 2005, 81, 339-346. [CrossRef]

11. Klimaszewska, K. Plantlet development from immature zygotic embryos of hybrid larch through somatic embryogenesis. Plant Sci. 1989, 63, 95-103. [CrossRef]

12. Von Aderkas, P.; Klimaszewska, K.; Bonga, J.M. Haploid and diplod embryogenesis in Larix leptolepis, L. decidua and their reciprocal hybrids. Can. J. For. Res. 1990, 20, 9-14. [CrossRef] 
13. Klimaszewska, K.; Devantier, Y.; Lachance, D.; Lelu, M.A.; Charest, P.J. Larix laricina (Tamarack) somatic embryogenesis and genetic transformation. Can. J. For. Res. 1997, 27, 538-550. [CrossRef]

14. Thompson, R.G.; Von Aderkas, P. Somatic embryogenesis and plant regeneration from immature embryos of western larch. Plant Cell Rep. 1992, 11, 379-385. [CrossRef]

15. Lü, S.F.; Zhang, S.G.; Qi, L.W.; Sun, X.M.; Wang, J.F. Somatic embryogenesis from immature embryos of Larix kaempferi. Sci. Silvae Sinicae 2005, 41, 48-52.

16. Song, Y.; Zhen, C.; Zhang, H.; Li, S. Embryogenic Callus Induction and Somatic Embryogenesis from Immature Zygotic Embryos of Larix olgensis. Sci. Silvae Sin. 2016, 52, 45-54.

17. Xie, Z.L.; Li, D.; Chen, Y.S.; Yu, X.J.; Gu, X.; He, C.Z. Induction of Embryonic Callus of Pinus yunnanensis. J. Southwest For. Univ. Nat. Sci. 2019, 39, 28-34.

18. Yang, H.H.; Wang, Z.W.; Yang, J.L. Research Progress on Somatic Embryogenesis in Pinaceae. J. Temp. For. Res. 2021, 4, 1-8.

19. Song, Y.; Li, S.; Zhang, H.; Bai, X.; Dong, H. Establishment and Optimization of Embryogenic Callus Suspension Culture System of Larix. Sci. Silvae Sin. 2018, 54, 146-154.

20. Pullman, G.S.; Johnson, S.; Peter, G.; Cairney, J.; Xu, N. Improving loblolly pine somatic embryo maturation: Comparison of somatic and zygotic embryo morphology, germination, and gene expression. Plant Cell Rep. 2003, 21, 747-758. [CrossRef] [PubMed]

21. Biddington, N.L. The influence of ethylene in plant tissue culture. Plant Growth Reg. 1992, 11, 173-187. [CrossRef]

22. Jean-Paul, R.; Alain, L.; Jean, F. Role of ethylene on induction and expression of carrot somatic embryogenesis: Relationship with polyamine metabolism. Plant Sci. 1994, 103, 223-229.

23. Qi, L.W.; Han, Y.F.; Li, L.; Ewald, D.; Han, S.Y. Study on effect of ABA, PEG4000 and AgNO3 on number of somatic embryos of Larix principis-rupprechtii by 311-A regression design. Chin. J. Biotech. 2001, 17, 84-89.

24. Song, Y.; Li, S.; Bai, X.; Zhang, H. Screening and verification of the factors influencing somatic embryo maturation of Larix olgensis. J. For. Res. 2018, 29, 1581-1589. [CrossRef]

25. Peng, C.; Gao, F.; Wang, H.; Shen, H.; Yang, L. Optimization of maturation process for somatic embryo production and cryopreservation of embryogenic tissue in Pinus koraiensis. Plant Cell Tissue Organ Cult. 2021, 144, 185-194. [CrossRef]

26. Li, D. Study on Larch Zygotic Embryo Development and Somatic Embryo Induction; Beijing Forestry University: Beijing, China, 2013.

27. Klimaszewska, K.; Lachance, D.; Pelletier, G.; Lelu, A.-M.; Seguin, A. Regeneration of transgenic Picea glauca, P. Mariana, and P. abies after cocultivation of embryogenic tissue with Agrobacterium tumefaciens. Vitr. Cell. Dev. Biol. 2001, 37, 748-755. [CrossRef]

28. Litvay, J.D.; Verma, D.C.; Johnson, M.A. Influence of loblolly pine (Pinus taeda L.) culture medium and its components on growth and somatic embryogenesis of wild carrot (Daucus carota L.). Plant Cell Rep. 1985, 4, 325-328. [CrossRef]

29. Park, Y.S.; Barrett, J.D.; Bonga, J.M. Application of somatic embryogenesis in high-value clonal forestry: Deployment, genetic control, and stability of cryopreserved clones. Vitr. Cell. Dev. Biol. 1998, 34, 231-239. [CrossRef]

30. Zhang, C.X.; Qian, L.; Kong, L. Induction, development and maturation of somatic embryos in Bunge's pine (Pinus bungeana Zucc. ex Endl.). Plant Cell Tissue Organ Cult. 2007, 91, 273-280. [CrossRef]

31. Chen, S. Optimization of Somatic Embryogenesis in Picea likiangensis (Franch.) Pritz and Proteomic Analysis on SEs at Developmental Stages; Yunnan University: Yunnan, China, 2010.

32. Park, Y.S.; Lelu-Walter, M.A.; Harvengt, L.; Trontin, J.F.; Maceacheron, I.; Klimaszewska, K.; Bonga, J.M. Initiation of somatic embryogenesis in Pinus banksiana, P. strobus, P. pinaster, and P. sylvestris at three laboratories in Canada and France. Plant Cell Tissue Organ Cult. 2006, 86, 87-101. [CrossRef]

33. Pullman, G.S.; Bucalo, K. Pine somatic embryogenesis: Analyses of seed tissue and medium to improve protocol development. New For. 2014, 45, 353-377. [CrossRef]

34. Maruyama, T.E.; Hosoi, Y. Progress in Somatic Embryogenesis of Japanese Pines. Front. Plant Sci. 2019, 10, 1-15. [CrossRef] [PubMed]

35. Ebert, A.; Taylor, H.F. Assessment of the changes of 2,4-dichlorophenoxyacetic acid concentrations in plant tissue culture media in the presence of activated charcoal. Plant Cell Tissue Organ Cult. 1990, 20, 165-172.

36. Pullman, G.S.; Gupta, P.K.; Timmis, R.; Carpenter, C.; Kreitinger, M.; Welty, E. Improved Norway spruce somatic embryo development through the use of abscisic acid combined with activated carbon. Plant Cell Rep. 2005, 24, 271-279. [CrossRef]

37. Rai, M.K.; Shekhawat, N.S.; Harish Gupta, A.K.; Jaiswal, U. The role of abscisic acid in plant tissue culture-a review of recent progress. Plant Cell Tissue Organ Cult. 2011, 106, 179-190. [CrossRef]

38. Hugo, P.F.F.; Leila, N.V.; Catarina, C.P. Glutathione and abscisic acid supplementation influences somatic embryo maturation and hormone endogenous levels during somatic embryogenesis in Podocarpus lambertii Klotzsch ex Endl. Plant Sci. 2016, 253, 98-106.

39. LW, Q. Studies on the somatic embryogenesis and establishment of experimental system in Larixprincipis-Rupprechtii. Acta Biol. Exp. Sinica. 2000, 33, 358-365.

40. Lelu-Walter, M.A.; Gautier, F.; Eliásová, K.I.; Sanchez, L.; Teyssier, C.; Lomenech, A.M.; Metté, C.L.; Hargreaves, C.; Trontin, J.F.O.; Reeves, C. High gellan gum concentration and secondary somatic embryogenesis: Two key factors to improve somatic embryo development in Pseudotsuga menziesii. Plant Cell Tissue Organ Cult. 2018, 132, 137-155. [CrossRef]

41. Gupta, P.K.; Pullman, G.S. Method for reproducing coniferous plants by somatic embryogenesis using abscisic acid and osmotic potential variation. US Patent 5036007, 18 September 1990. 
42. Klimaszewska, K.; Bernier-Cardou, M.; Cyr, D.R.; Sutton, B.C.S. Influence of gelling agents on culture medium gel strength, water availability, tissue water potential, and maturation response in embryogenic cultures of Pinus strobus L. Vitr. Cell. Dev. Biol. Plant 2000, 36, 279-286. [CrossRef]

43. Klimaszewska, K.; Smith, D.R. Maturation of SEs of Pinus strobus is promoted by a high concentration of gellan gum. Physiol. Plant. 2010, 100, 949-957. [CrossRef]

44. Yang, J.; Gui, Y.; Yang, Y. Somatic embryogenesis and plantlet regeneration in mature zygotic embryos of Picea Meyeri. Acta Bot. Sinica. 1997, 39, 315-321.

45. Lelu, M.; Bastien, C.; Drugeault, A. Somatic embryogenesis and plantet development in Pinus sylvestris and Pinus pinaster on medium with and without growth regulators. Physiol. Plant. 1999, 105, 719-728. [CrossRef]

46. Lelu-Walter, M.; Pâques, L.E. Simplified and improved somatic embryogenesis of hybrid larches (Larix $\times$ eurolepis and Larix $\times$ marschlinsii). Perspectives for breeding. Ann. For. Sci. 2009, 66, 104. [CrossRef]

47. Hosoi, Y.; Maruyama, T.E. Plant regeneration from embryogenic tissue of Pinus luchuensis Mayr, an endemic species in Ryukyu Island, Japan. Plant Biotechnol. 2012, 29, 401-406. [CrossRef]

48. Teyssier, C.; Grondin, C.; Bonhomme, L.; Lomenech, A.M.; Vallance, M.; Morabito, D.; Label, P.; Lelu-Walter, M.A. Increased gelling agent concentration promotes somatic embryo maturation in hybrid larch (Larix $\times$ eurolepsis): A 2-DE proteomic analysis. Physiol. Plant. 2011, 141, 152-165. [CrossRef] [PubMed]

49. Attree, S.M.; Fowke, L.C. Embryogeny of gymnosperms: Advances in synthetic seed technology of conifers. Plant Cell Tissue Organ Cult. 1993, 35, 1-35. [CrossRef]

50. Durzan, D.J.; Gupta, P.K. Biotechnology of somatic polyembryogenesis and plantlet regeneration in loblolly pine. BioTechnology 1987, 5, 147-151.

51. Becwar, M.R.; Nagmani, R.; Wann, S.R. Initiation of embryogenic cultures and somatic embryo development in loblolly pine (Pinus taeda). Can. J. For. Res.-Rev. Can. De. Rech. For. 1990, 20, 810-817. [CrossRef]

52. Salajova, T.; Salaj, J. Somatic embryogenesis in Pinus nigra: Embryogenic tissue initiation, maturation and regeneration ability of established cell lines. Biol. Plant 2005, 49, 333-339. [CrossRef]

53. Maruyama, T.E.; Hosoi, Y.; Ishii, K. Propagation of Japanese red pine (Pinus densiflora Zieb. etZucc.) via somatic embryogenesis. Propag Ornam Plant. 2005, 5, 199-204.

54. Maruyama, E.; Hosoi, Y.; Ishii, K. Somatic embryogenesis and plant regeneration in yakutanegoyou, Pinus armandii Franch. var. amamiana (Koidz.) Hatusima, an endemic and endangered species in Japan. Vitr. Cell. Dev. Biol. Plant 2007, 43, 28-34. [CrossRef]

55. Klimaszewska, K.; Park, Y.; Overton, C.; Maceacheron, I. Optimized Somatic Embryogenesis in Pinusstrobus L. Vitr. Cell. Dev. Biol. Plant 2001, 37, 392-399. [CrossRef]

56. Lelu-Walter, M.; Bernier-Cardou, M.; Klimaszewska, K. Simplified and improved somatic embryogenesis for clonal propagation of Pinuspinaster (Ait.). Plant Cell Rep. 2006, 25, 767-776. [CrossRef] [PubMed]

57. Ahn, C.-H.; Choi, Y.-E. In vitro clonal propagation and stable cryopreservation system for Platycladus orientalis via somatic embryogenesis. Plant Cell Tissue Organ Cult. 2017, 131, 513-523. [CrossRef]

58. Kim, Y.W.; Moon, H.K. Enhancement of somatic embryogenesis and plant regeneration in Japanese larch (Larix leptolepis). Plant Cell Tissue Organ Cult. 2007, 88, 241-245. [CrossRef]

59. Pan, M.J.; van Staden, J. The use of charcoal in vitro culture-A review. Plant Growth Reg. 1998, 26, 155-163. [CrossRef]

60. von Aderkas, P.; Label, P.; Lelu, M.A. Charcoal affects early development and hormonal concentrations of SEs of hybrid larch. Tree Physiol. 2002, 22, 431-434. [CrossRef]

61. Thomas, T.D. The role of activated charcoal in plant tissue culture. Biotechnol. Adv. 2008, 26, 618-631. [CrossRef]

62. Winkle, S.C.; Pullman, G.S. The combined impact of $\mathrm{pH}$ and activated carbon on the elemental composition of a liquid conifer embryogenic tissue initiation medium. Plant Cell Rep. 2003, 22, 303-311. [CrossRef]

63. van Winkle, S.C.; Johnson, S.; Pullman, G.S. The impact of Gelrite and activated carbon on the elemental composition of two conifer embryogenic tissue initiation media. Plant Cell Rep. 2003, 21, 1175-1182. [CrossRef]

64. Rodríguezgacio, M.D.C.; Matillavázquez, M.A.; Matilla, A.J. Seed dormancy and ABA signaling: The breakthrough goes on. Plant Signal. Behavior. 2009, 4, 1035. [CrossRef]

65. Vondrakova, Z.; Dobrev, P.I.; Pesek, B.; Fischerova, L.; Vagner, M.; Motyka, V. Profiles of Endogenous Phytohormones Over the Course of Norway Spruce Somatic Embryogenesis. Front. Plant Sci. 2018, 9, 1-13. [CrossRef]

66. Roberts, D.R.; Sutton, B.C.S.; Flinn, B.S. Synchronous and high frequency germination of interior spruce SEs following partial drying at high relative humidity. Can. J. Bot. 1990, 68, 1086-1090. [CrossRef]

67. Beardmore, T.; Charest, P.J. Black spruce somatic embryo germination and desiccation tolerance. I. Effects of abscisic acid, cold, and heat treatments on the germinability of mature black spruce SEs. Can. J. For. Res. 1995, 25, 1763-1772. [CrossRef]

68. Jones, N.B.; van Staden, J. Improved somatic embryo production from embryogenic tissue of Pinus patula. Vitr. Cell. Dev. Biol. Plant 2001, 37, 543-549. [CrossRef]

69. Bonga, J.M.; Klimaszewska, K.K.; von Aderkas, P. Recalcitrance in clonal propagation, in particular of conifers. Plant Cell Tissue Organ Cult. 2010, 100, 241-254. [CrossRef]

70. Kharenko, O.A.; Zaharia, L.I.; Giblin, M.; Eki, V.; Taylor, D.C.; Palmer, C.D.; Abrams, S.R.; Loewen, M.C. Abscisic acid metabolism and lipid accumulation of a cell suspension culture of Lesquerella fendleri. Plant Cell Tissue Organ Cult. 2011, 105, 415-422. [CrossRef] 
71. Abrahamsson, M.; Valladares, S.; Larsson, E.; Clapham, D.; Arnold, S. Patterning during somatic embryogenesis in Scots pine in relation to polar auxin transport and programmed cell death. Plant Cell Tissue Organ Cult. 2012, 109, 391-400. [CrossRef]

72. Liao, Y.K.; Juan, I. Improving the germination of SEs of Picea morrisonicola Hayata: Effects of cold storage and partial drying. J. For. Res. 2015, 20, 114-124. [CrossRef]

73. Pullman, G.S.; Olson, K.; Fischer, T.; Egertsdotter, U.; Frampton, J.; Bucalo, K. Fraser fir somatic embryogenesis: High frequency initiation, maintenance, embryo development, germination and cryopreservation. New For. 2016, 47, 1-28. [CrossRef] 